\title{
Constitutional Piety: The Integration of Anti-Corruption Education into Islamic Religious Learning Based on Neuroscience
}

\author{
${ }^{1}$ Suyadi; ${ }^{2}$ Sumaryati; ${ }^{3}$ Dwi Hastuti; ${ }^{4}$ Desfa Yusmaliana; ${ }^{5}$ Rafika Dwi Rahmah MZ \\ Universitas Ahmad Dahlan, Indonesia \\ 11suyadi@fai.uad.a.id ; ${ }^{2}$ sumaryati@ppkn.uad.ac.id; ${ }^{3}$ dwi.hastuti@pgpaud.uad.ac.id; \\ 4yusmaliana.desfa@yahoo.co.id; 5rafikadrmz1605@gmail.com
}

\begin{abstract}
The new phenomenon of corruption cases that ensnared Islamic religious leaders in Indonesia indicates that so far Islamic education in Indonesia has not taught anti-corruption. As a result, religious leaders only have ritual and social piety, but do not yet have constitutional piety. From a neuroscience perspective, Corruptor's brain is basically normal but not healthy. The purpose of this study is to find a conceptual model of the integration of anti-corruption education in neurosciencebased Islamic religious learning to develop character constitutional piety. The research approach used is qualitative method in the form of Creswell model library research. Data sources are obtained from literature in the field of Islamic education, anti-corruption, and neurosciences. The Sugiyono model was performed to collect the data, namely by searching related literature, both manually and digitally. The data were then analyzed using Moleong's content analysis. The results showed that the character of constitutional piety could be developed in students through anti-corruption education integrated with neuroscience-based Islamic religious learning. Seven forms of corruption (detrimental to the state, bribery, embezzlement, extortion, cheating, conflict of interest and gratification) are examined in perspective of jinayah jurisprudence and or anti-corruption jurisprudence (al- ghûl, riswah, khiyanat, ghasbah) then formally configured. The anticorruption education model in Islamic religious learning based on neuroscience has the potential to develop the character of ritual, social and constitutional piety integrally.
\end{abstract}

Keywords. Islamic Education; Anti-corruption; Neuroscience; Ritual Piety; Social and Constitutional.

\begin{abstract}
Abstrak. Fenomena baru tentang kasus-kasus korupsi yang menjerat para pemuka agama Islam di Indonesia mengindikasikan bahwa selama ini pendidikan Islam di Indonsia belum mengajarkan antikorupsi. Akibatnya, pemuka agama hanya memiliki kesalehan ritual dan maksimal kesalehan sosial, namun belum memiliki kesalehan konstitusional. Dalam perspektif neurosains, otak Koruptor hanya normal tetapi tidak sehat. Tujuan penelitian ini adalah menemukan model konseptual tentang integrasi pendidikan antikorupsi dalam pembelajaran keagamaan Islam berbasis neurosains untuk mengembangkan karakter kesalehan konstitusional. Pendekatan penelitian yang digunakan adalah kualitatif dalam bentuk penelitian kepustakaan model Creswell. Sumber data diperoleh dari literatur-literatur di bidang pendidikan Islam, antikorupsi dan neurosains. Teknik pengumpulan data menggunakan model Sugiyono, yakni dengan melakukan penelusuran terhadap literatur terkait, baik secara manual maupun digital. Teknik analisis data menggunakan konten analisis model Moleong. Hasil penelitian menunjukkan bahwa karakter kesalehan konstitusional dapat dikembangkan dalam diri peserta didik melalui pendidikan antikorupsi yang terintegrasi dengan pembelajaran keagamaan Islam berbasis neurosains. Tujuh bentuk korupsi (merugikan negara, suap, penggelapan, pemerasan, curang, benturan kepentingan, dan gratifikasi) dikaji dalam perspektif fikih jinayah dan atau fikih antikorupsi (al-ghûl, riswah, khiyanat, ghasbah) kemudian diformulasikan secara konfiguratif. Model pendidikan antikorupsi dalam pembelajaran keagamaan Islam berbasis neurosains inilah yang berpotensi mengembangkan karakter kesalehan ritual, sosial dan konstitusional secara integral.
\end{abstract}

Kata kunci: Pendidikan Islam, antikorupsi, neurosains, kesalehan ritual, sosial, dan konstitusional.

Copyright (C) J-PAI: Jurnal Pendidikan Agama Islam. All Right Reserved.

This is an open-access article under the CC BY-SA license

(https://creativecommons.org/licenses/by-sa/4.0/).

Correspondence Address: jpai@uin-malang.ac.id 


\section{A. INTRODUCTION}

The academic problem raised in this study is the continuing increase of the number of corruptors from religious circles, as experienced by some religious leaders in Indonesia such as SDA, LHI, IH, and finally IN. The ministry of religion which should be the "holiest ministry" in reality becomes the most corrupt ministry (Rumadi, 2017). Evidence shows there are three ministers of religion who were suspected by the Corruption Eradication Commission or known as KPK. Meanwhile, ironically the Ministry of Religion should be the one who works alongside KPK to eradicate corruption. In the context of national and state life, a Muslim who is devout in worship but committed corruption is only religiously and socially pious, but does not have constitutional piety.

Law enforcement, unfortunately, does not cater to long term eradication goals, even when the death penalty is applied. For example, China has imposed the death penalty for corruptors, but until now this state is still not corruption-free (Gong, Wang, \& Ren, 2015), (Li, Gong, \& Xiao, 2016). This shows that law enforcement alone is not sufficient to eradicate this ingrained crime. Some studies suggest that the eradication of corruption must be carried out with early prevention in a systematic and structured way (Sumaryati, Suyadi, 2019), one of which is through Islamic education at all levels of education (Suyadi, 2015b). Thus, Islamic education not only teaches morality, faith and piety (Fauzi \& Hamid, 2018) which only makes learners pious in personal-ritual and social terms, but also constitutional piety.

Despite knowing the importance of preventive measures, however, Suyadi's research shows that so far Islamic education has not taught anti-corruption values which serve as the basis of prevention (Suyadi, 2015b). The values of honesty, kindness, moral truth, even faith, and piety that only train students to be personally and socially pious are believed to be inadequate to prevent corrupt behavior. There have been myriad proofs showing various religious leaders who were previously trusted by the community or people as a role model, but turn out to be very corruptive when given the mandate by the government in certain positions and thus suggest that he does not have constitutional piety. This shows that Islamic religious education like morals, faith, and devotion are not enough to build the nation's generation which has built-in anti-corruption character.

The core reason which may explain why Islamic education is not able to build an anti-corruption character so that it fails to form constitutional piety is that so far Islamic education is still taught normatively and dogmatically, not rationally and empirically (Suyadi, 2018a), (Suyadi, 2016). As a result, religion is only a ceremony, and it is not honored and practiced. Religious teachings are practiced only as a ritual aspect so that most Muslims are piously ritualized (M. A. Hidayat, 2017). Others also practice social aspects of religious teachings, so that besides religiously pious they are also socially pious (Teak \& Central, 2015). But what is still rarely practiced is piety in a constitutional manner, so that social and religious figure is not necessarily culturally pious. A corrupt person, despite diligently worshipping (ritually pious) and often giving charity (socially pious), is not pious constitutionally. On this basis, Islamic education must be able to develop constitutional piety, in addition to personal and social ritual piety.

Therefore, a new approach in Islamic education which is not simply normative and dogmatic is needed so that it does not only produce religious-personality but also socially pious students. Kong also suggested using new approaches in preventing corruption, because so far the effort done in numerous studies mainly concerns with legal, psychological and economic approaches (Kong, 2017). In this case, the authors use a neuroscience approach, arguing that the corrupt brain is only normal but not healthy.

Pasiak said that character education is brain education (Pasiak, 2018). There are six brain components that regulate behavior, including anti-corruption behavior, which are: 
Suyadi, dkk: Constitutional Piety: The Integration of Anti-Corruption Education...

the prefrontal cortex, limbic system, cingulate gyrus, basal ganglia, temporal lobe, and cerebellum (Pasiak, 2012). The six components of the brain do not work separately, but they are interrelated to each other to form a network of circuits that ordering to do or not do something. Based on these concepts, this study analyzed the anti-corruption education model in Islamic education based on neuroscience (rational and empirical) that can produce not only ritually pious-personal but also socially and constitutionally pious students.

The formulation of the concept like this is still rarely discussed because most studies prefer direct to the foremost model of anti-corruption education, but they are not based on rational and empirical neuroscience yet. Therefore, a new kind of piety is needed to answer the problem which has scraped away Indonesia as a nation, which is corruption. This new piety is constitutional piety, namely the piety of statesmen who believe and devote to God Almighty. Thus, the purpose of this study is to find a conceptual model of anti-corruption education in learning Islam based on neuroscience that is able to develop constitutional piety for students. This new discovery will complement the lack of Islamic education which has so far only shaped normative and dogmatic ritual-personal and social piety.

\section{B. RESEARCH METHODS}

This research approach is qualitative in the form of library research (Creswell, 2015). The data source of this research is literature both from books and journals in the fields of Islamic education, anti-corruption, and neuroscience. The following table 1 is the data source in this literature study.

\begin{tabular}{|c|c|c|c|c|}
\hline No & Author(s) & Title & Publisher & Year \\
\hline 1. & $\begin{array}{l}\text { Taufiq } \\
\text { Pasiak }\end{array}$ & $\begin{array}{l}\text { Tuhan Dalam Otak Manusia: Mewujudkan Kesehatan } \\
\text { Spiritual Berdasarkan Neurosains. }\end{array}$ & $\begin{array}{l}\text { Bandung: } \\
\text { Mizan }\end{array}$ & 2012 \\
\hline 2. & $\begin{array}{l}\text { Taufiq } \\
\text { Pasiak }\end{array}$ & $\begin{array}{l}\text { Revolusi IQ/EQ/SQ: Menyingkap Rahasia Kecerdasan } \\
\text { Berdasarkan Al-Quran dan Neurosains Mutakhir. }\end{array}$ & $\begin{array}{l}\text { Bandung: } \\
\text { Mizan }\end{array}$ & 2008 \\
\hline 3. & $\begin{array}{l}\text { Taufiq } \\
\text { Pasiak }\end{array}$ & $\begin{array}{l}\text { Pendidikan Karakter sebagai Pendidikan Otak. In } \\
\text { Mengatasi Masalah Narkoba dengan Welas Asih. }\end{array}$ & $\begin{array}{l}\text { Jakarta: Gramedia } \\
\text { Pustaka Utama }\end{array}$ & 2012 \\
\hline 4. & $\begin{array}{l}\text { Taufiq } \\
\text { Pasiak }\end{array}$ & $\begin{array}{l}\text { Spiritual Neuroscience: Behavioral Implication in } \\
\text { Health and Leadership. }\end{array}$ & $\begin{array}{l}\text { Manado: POPS- } \\
\text { LPPM Unsrat }\end{array}$ & 2018 \\
\hline 5. & $\begin{array}{l}\text { Squire Larry } \\
\text { R. (ed) }\end{array}$ & Fundamental Neuroscience, Third Edition. & $\begin{array}{l}\text { London: Elsevier \& } \\
\text { AP }\end{array}$ & 2008 \\
\hline 6. & $\begin{array}{l}\text { Sherwood } \\
\text { Lauralee }\end{array}$ & $\begin{array}{l}\text { Fisiologi Manusia, dari Sel ke Sistem; alih bahasa: } \\
\text { Brahm U. Pendit, Edisi VI }\end{array}$ & $\begin{array}{l}\text { Jakarta: Penerbit } \\
\text { Buku Kedokteran } \\
\text { EGC }\end{array}$ & 2012 \\
\hline 7. & $\begin{array}{l}\text { Snell } \\
\text { Richard S. }\end{array}$ & $\begin{array}{l}\text { Neuroanatomi Klinik, alih bahasa: Liliana Sugiharto, } \\
\text { Edisi VII }\end{array}$ & $\begin{array}{l}\text { Jakarta: EEG } \\
\text { Penerbit Buku } \\
\text { Kedokteran, }\end{array}$ & 2013. \\
\hline 8. & Suyadi & $\begin{array}{l}\text { Dasar-Dasar Pemikiran Menuju Ilmu Neurosains } \\
\text { Pendidikan Islam (Optimalisasi Potensi Otak Dalam } \\
\text { Pembelajaran Anak Usia Dini). }\end{array}$ & $\begin{array}{l}\text { Pascasarjana, } \\
\text { Yogyakarta. }\end{array}$ & 2015 \\
\hline 9. & Suyadi & Pembelajaran Anak usia Dini Dalam Kajian Neurosains. & $\begin{array}{l}\text { Bandung: Rosda } \\
\text { Karya. }\end{array}$ & 2016 \\
\hline 10. & Suyadi & $\begin{array}{l}\text { Diferensiasi Otak Laki-laki dan Perempuan Guru } \\
\text { Taman Kanak-kanak Aisyiyah Nyai Ahmad Dahlan } \\
\text { Yogyakarta: Studi Pendidikan Islam Anak Usia Dini } \\
\text { Perspektif Gender dan Neurosains. }\end{array}$ & $\begin{array}{l}\text { Sawwa: Jurnal Studi } \\
\text { Gender, 13(2), 179- } \\
202 .\end{array}$ & 2018 \\
\hline 11. & Suyadi & $\begin{array}{l}\text { Pendidikan Islam Anak Usia Dini Dalam Perspektif } \\
\text { Neurosains: Robotik Akademik Dan Saintifik. }\end{array}$ & $\begin{array}{l}\text { Edukasia: Jurnal } \\
\text { Penelitian } \\
\text { Pendidikan Islam, } \\
\text { 13(2), 231-262. }\end{array}$ & 2018 \\
\hline 12. & Suyadi & The Synergy of Arts, Neuroscience, and Islamic In Early & Tarbiya: Journal of & 2018 \\
\hline
\end{tabular}


J-PAI : Jurnal Pendidikan Agama Islam, Vol. 6 No. 1 Juli-Desember 2019

\begin{tabular}{|c|c|c|c|}
\hline & Childhood Learning In Yogyakarta. & $\begin{array}{l}\text { Education in Muslim } \\
\text { Society, 5(1), 30-42. }\end{array}$ & \\
\hline 13. Suyadi & $\begin{array}{l}\text { Hybridization of Islamic Education and Neuroscience: } \\
\text { Transdisciplinary Studies of 'Aql in the Quran and the } \\
\text { Brain in Neuroscience. }\end{array}$ & $\begin{array}{l}\text { Dinamika Ilmu, } \\
19(2), 1-20 .\end{array}$ & 2019 \\
\hline 14. Suyadi & $\begin{array}{l}\text { Mainstreaming the Knowledge of Islamic Education } \\
\text { With Progress and of Islam Nusantara Education. }\end{array}$ & $\begin{array}{l}\text { Akademika, 24(1), } \\
37-66 .\end{array}$ & 2019 \\
\hline 15. Suyadi & $\begin{array}{l}\text { Millennialization of Islamic Education Based on } \\
\text { Neuroscience in the Third Generation University in } \\
\text { Yogyakarta Indonesia. }\end{array}$ & $\begin{array}{l}\text { QIJIS : Qudus } \\
\text { International Journal } \\
\text { of Islamic Studies, } \\
7(1), 173-202 .\end{array}$ & 2019 \\
\hline
\end{tabular}

Data collection is done by searching for related references, both manually and digitally. The data collected is then displayed, reduced and constructed into a new concept that is intact and fresh (Sugiyono, 2015).

Data analysis was performed using content analysis (Moleong, 2014) which emphasizes intertextuality. The literature in the anti-corruption field is confirmed by the literature in the field of Islamic education, then both are clarified with empirical findings in the field of neuroscience. At the same time the literature in the field of neuroscience was conceptualized into Islamic education. The integration of the three forms the integrity of a new meaning, namely constitutional piety.

\section{RESULTS AND DISCUSSION}

Based on the problems formulated and the applied research methodology, the results of this study were organized into two sub-points, namely the integration of anticorruptive education in Islamic religious learning based on neuroscience and constitutional piety. The integration model of anti-corruption education in neuroscience-based Islamic religious learning is a theoretical concept of rational and empirical integration of Islamic education and anti-corruption. Thus, anti-corruption education can be taught in an integrated manner in Islamic religious education at all levels of education. The ritualpersonal, social and constitutional piety discusses the expected learning outcomes of the concept or theoretical model of the integration of anti-corruption education in neuroscience-based Islamic religious learning. The three types of piety will be arranged in a hierarchical manner, where constitutional piety is the highest piety as an Islamic citizen in Indonesia.

\section{Anticorruption Education Integration Model in Neuroscience-based Islamic Religious learning}

Before arriving at the model of the integration of anti-corruption education into neuroscience-based Islamic religious learning, it is necessary to briefly state each concept discussed in this study, namely corruption, Islamic religious learning, and neuroscience. The three concepts are then constructed into new integrative concepts.

First, the word corruption comes from the Latin "corruptio" or "corruptus" which means rotten, bad, depraved, dishonest, can be bribed, immoral, deviation from holiness (Karsona, 2011). From this word, "corruptio" comes the word "corruption" in English or "corruptie / korruptie" in Dutch which has a similar meaning to the original word. Nownes added the term "lobby" which was commensurate with corruption (Nownes, 2017). In terminology, corruption is defined as an extraordinary crime. The forms of corruption are grouped into 7 seven, namely: harmful to state finances, bribery, embezzlement in office, extortion, cheating, conflict of interest in procurement, and gratification (KPK, 2006). In jinayah fiqh, (Alim, 2017) corruption is referred to as al-rishwah, al-suht, and al-ghûl (Umam, 2013). Corruption in Arabic, better known as "ghulul" which means embezzlement 
Suyadi, dkk: Constitutional Piety: The Integration of Anti-Corruption Education...

or "riswah" which means bribery or other equivalent words, such as ghasbah (cheating), khiyanat (abuse of authority), and maxim (illegal levies) (Mustakim, 2013).

Second, Islamic religious learning terminologically is the same as "Islamic religious education", because Islam is the name of religion. But etymologically, both have different meanings; "Islamic Education" is an Islamic education system, so that other related components (theory, curriculum, methods, evaluations, etc.) are composed of the Qur'an and Hadith. While the term "Islamic Religious Education" (PAI), is more as "the name of learning activities." Islamic education research here refers to learning activities or Islamic Religious Education (PAI), not an education system based on the Qur'an and Hadith on a larger scale.

Third, neuroscience is a neural science that studies the nervous system, especially studying neurons or nerve cells, with a multidisciplinary approach (Pasiak, 2016). Neuroscience is also a field of science that specializes in scientific studies of the nervous system (neuroanatomy) and all nerve functions (neurophysiology). This science is a science that in the 21st century experienced very rapid development, crossed in various other scientific disciplines, such as psychology (neuropsychology), economics (neuroeconomics), leadership (neuro-leadership), marketing (neuromarketing), education (education-neuroeducation), art (arts-neuro art) and others (Pledge, 2016), (Suyadi, 2018b).

In the context of Islamic education, Suyadi has laid the foundations of thought towards a new science which he called the neuroscience of Islamic education (Suyadi, 2015). Neuroanatomically, the biological organs of the brain in the Qur'an can be found in the QS. Al-'Alaq (15-16) edited with the word "nasiyah" (crown), which in the perspective of science is interpreted as "the brain" especially the prefrontal cortex (McKlveen, Myers, \& Herman, 2015), (ITB, 2014). In neurophysiology, namely the function of the brain itself, the Qur'an is very rich in neuroscience such as dabbara (contemplating), faqiha (understanding), fahima (understanding), nazhara (seeing with the eyes), dzakara (remembering), fakkara (thinking) depth), and 'alima (understand clearly) (Pasiak, 2008).

Based on the explanation of corruption, Islamic religious learning and neuroscience above, the integration of anti-corruption education in Islamic religious learning based on neuroscience is a combination of anti-corruption education and Islamic learning whose processes are carried out rationally and empirically as the brain works. Thus, anticorruption can be taught in an integrated manner with Islamic Religious Education subjects at all levels of education without adding new subjects. Anti-corruption values such as honesty, fairness, simplicity, hard work, etc. (Sumaryati, Suyadi, 2019) can be combined with universal Islamic values, such as trustworthiness, (siddiq, fathanah,) and so on. And vice versa, seven forms of corruption (financially harmful to the state, bribery, embezzlement, blackmail, cheating, conflict of interest, and gratification) are examined in the perspective of jurisprudence (al-ghulw, risywah, khiyanat, ghasbah) (Anwar, 2006). Thus anti-corruption education and Islamic education can go hand in hand and balanced.

The neuroscience in the context of the integration of anti-corruption education in Islamic religious learning is limited to learning strategies, so that Islamic education is not always dogmatic and normative, but also rational and empirical (Sa'adi, 2011). Just for example, in neuroscience many brain-based learning strategies have been developed, one of which is brain-based learning (Jensen, 2000). This strategy can be used to teach anticorruption education in Islamic religious learning. If the model of integration of anticorruption education in Islamic religious learning is depicted in a chart, it will look like the following figure 1 . 


\section{Figure 1. \\ Integration Model of Neuroscience-Based Anti-Corruption and Islamic Education Learning}

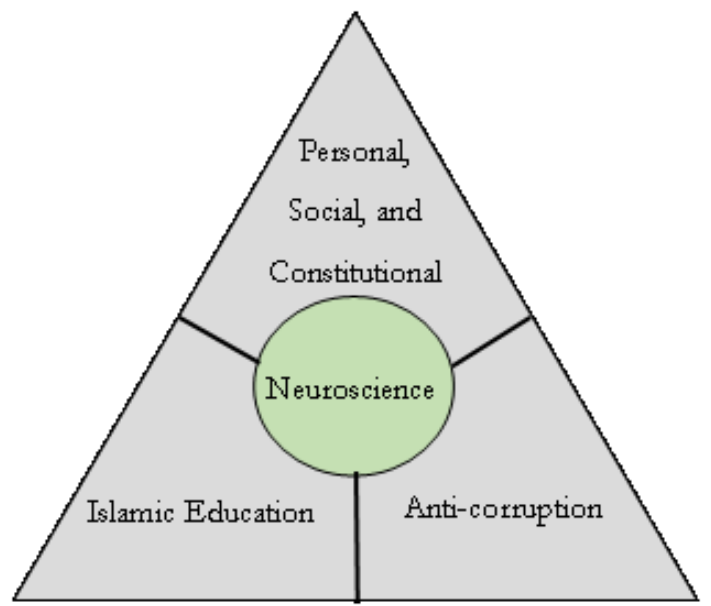

The anticorruption education integration model in Islamic religious learning based on neuroscience as shown in Figure 1 above has the potential to develop ritual-personal, socio-cultural, and constitutional piety. Normative Islamic religious learning must be developed or completely transformed into the empirical rationale, anti-corruption education must be in contact with the spirituality of Islamic theology, and neuroscience must combine the two. Thus, a learning process contains three scientific elements, namely anti-corruption, Islam, and neuroscience. This holistic education model has the potential to develop students' character holistically, both ritual-personal, socio-cultural and constitutional piety.

\section{Ritual-personal, Social and Constitutional Piety}

Ritual piety is the perseverance of someone in carrying out mahdzoh (core) worship, such as prayer, fasting, zakat, and even repeated pilgrimage (M. A. Hidayat, 2017), (M. A. Hidayat, 2017). Ritual piety can also be interpreted as a person or individual piety because this type of piety is special obedience between those which are owned by Allah SWT. It is this religious and personal ritual that distinguishes the piety of a Muslim from another.

Social piety is piety between a Muslim and others in general (Muqoyyidin, 2013). Social piety is very relative, the standard is determined by each social community or certain communities. Something considered good in social groups is not necessarily good for other social groups. Social piety is determined or used by most people for others. Ritual piety must imply social piety (Setiawan, 2016). But the reality is not always the case (A. Hidayat, 2017). The religious leaders who became corrupt were ritual pious people, but not socially pious. He is only good for his God, but not for others. Corruption is considered an extraordinary crime because corrupt victims are not victims of corruption. Thus, religious leaders who become corrupt are people who are repairing the separation of the soul or multiple personalities. From a neuroscience perspective, the brain is only normal but not healthy.

While constitutional piety is the original term of the researchers themselves, so the operational resolution is also based on scientific ijtihad (consensus) itself. Constitutional piety can play a role for citizens - including a Muslim - for the security and prosperity of their nation and country. it is a generation of nationals or citizens who can scent Indonesia with the capacity it has. If these three types of piety are illustrated in a chart, they will look like the following figure 2 . 
Figure 2.

\section{Hierarchical Structure of Ritual, Social and Constitutional Piety}

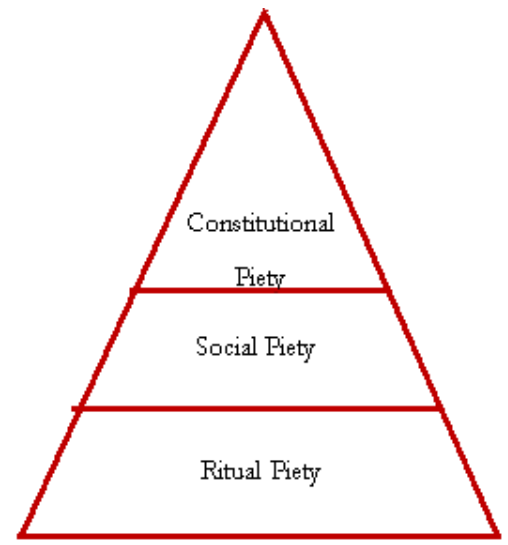

Ritually and socially pious people are also not necessarily pious constitutionally. Vice versa, people who have constitutional piety are not necessarily religiously and socially pious. For example, a law enforcement officer who rigidly sentenced someone to 10 years in prison because of stealing firewood is an example of constitutional piety that is not socially pious, and may also not ritually pious. Moreover, the law enforcers often actually impose light sentences for high-class corruptors.

Therefore, the piety needed by the Indonesian people is not only ritual piety or social piety, but Indonesia also does need constitutional piety. Indonesia needs a generation that has at least three devotions, namely ritual, social and constitutional piety. Islamic education must be able to answer the hopes of the Indonesian people, namely to build students' anti-corruption character, so that graduates of Islamic education have ritual, social and constitutional piety as well.

\section{CONCLUSION}

Constitutional piety is a criticism of Islamic education which has been less concerned with national problems, especially corruption. Islamic education has so far only taught Islamic character or character starting normatively so that it does not have a transformative impact on social religious change. Hence, Islamic education should teach anti-corruption to build a generation of millennial Muslims in a constitutionally pious future. Nevertheless, anti-corruption Islamic education should not only be taught in a normative, doctrinal and intellectual manner as in moral learning but also be historical, contextual, rational and empirical. On this basis, neuroscience offers a new approach to scientific anti-corruption Islamic education.

\section{REFERENCES}

Alim, M. W. dan H. (Ed.). (2017). Jihad Nahdlatul Ulama Melawan Korupsi. Jakarta: Lakpesdam-PBNU.

Anwar, S. (2006). Fikih Anti Korupsi Perspektif Ulama Muhammadiyah. Jakarta: Majelis Tarjih dan Tajdid Pimpinan Pusat Muhammadiyah.

Creswell, J. (2015). Riset Pendidikan: Perencanaan, Pelaksanaan, dan evaluasi Riset Kualitatif \& Kuantitatif. Yogyakarta: Pustaka Pelajar.

Fauzi, A., \& Hamid, A. (2018). Islamic Education in Malaysia. In Handbook of Islamic Education, International Handbooks of Religion and Education 7 (pp. 745-761). Panang, Malaysia: Springer International Publishing AG.

Gong, T., Wang, S., \& Ren, J. (2015). Corruption in the Eye of the Beholder: Survey Evidence from Mainland China and Hong Kong. International Public Management Journal, 18(3), 458-482. https://doi.org/10.1080/10967494.2015.1057629 
Hidayat, A. (2017). Peaceful in Pesantren: The Involvement of Santri 's Peaceful Environment and Personality. Al-Ta'lim Journal, 24(2), 79-92.

Hidayat, M. A. (2017). Ibadat, The Body And Identity: Islamic Rituals And The Construction Of Muslim Identity. The Journal of Society \& Media, 1(2), 1-17.

Ikrar, T. (2016). Ilmu Neurosains Modern. Yogyakarta: Pustaka Pelajar.

ITB, T. T. I. salman. (2014). Tafsir Salman: Tafsir Ilmiah Juz'amma. Bandung: Mizan dan YPM Salman ITB.

Jati, W. R., \& Pusat. (2015). Sufisme Urban di Perkotaan: Konstruksi Keimanan Baru Kelas Menengah Muslim. Jurnal Kajian \& Pengembangan Manajemen Dakwah, 05(02), 175199.

Jensen, E. (2000). Brain-Based Learning, The New Science of Teaching \& Training. California: Corwin Press.

Karsona, A. M. (211AD). Pengertian Korupsi. In Pendidikan Anti Korupsi untuk Perguruan Tinggi (p. 23). Jakarta: Kementerian Pendidikan dan Kebudayaan RI Direktorat Jenderal Pendidikan Tinggi.

Kong, D. T. (2017). An economic - genetic theory of corporate corruption across cultures : An interactive effect of wealth and the 5HTTLPR-SS / SL frequency on corporate corruption mediated by cultural endorsement of self-protective leadership. Personality And Individual Differences, 63 (November), 106-111. https://doi.org/10.1016/j.paid.2014.01.061

KPK. (2006). Memahami Untuk Membasmi. Jakarta: KPK.

Lexy J Moleong. (2014). Metodologi Penelitian Kualitatif Edisi Revisi. Bandung: Remaja Rosdakarya. Retrieved from http://www.bukukita.com/Referensi/ReferensiUmum/129449-Metodologi-Penelitian-Kualitatif-Edisi-Revisi.html

Li, H., Gong, T., \& Xiao, H. (2016). The Perception of Anti-corruption Efficacy in China: An Empirical Analysis. Social Indicators Research, 125(3), 885-903. https://doi.org/10.1007/s11205-015-0859-z

McKlveen, J. M., Myers, B., \& Herman, J. P. (2015). The Medial Prefrontal Cortex: Coordinator of Autonomic, Neuroendocrine and Behavioural Responses to Stress. Journal of Neuroendocrinology, 27(6), 446-456. https://doi.org/10.1111/jne.12272

Muqoyyidin, A. W. (2013). Dialektika Islam Dan Budaya Lokal Jawa. Ib'da Jurnal Kebudayaan Islam, Vol. 11, N.

Mustakim, M. (2013). Wawasan Al-Quran tentang Pendidikan Anti Korupsi. Jurnal Ilmu Tarbiyah "At-Tajdid," 2(1).

Nownes, A. (2017). Lobbying: The preconditions of an anti-corruption promise. AntiCorruption Resource Centre (Vol. 4). Australia.

Pasiak, T. (2018). Spiritual Neuroscience: Behavioral Implication in Health and Leadership. Manado: POPS-LPPM Unsrat.

Pasiak, T. (2016). Tuhan Dalam Otak Manusia: Mewujudkan Kesehatan Spiritual Berdasarkan Neurosains. Mizan, Bandung.

Pasiak, T. (2012). Pendidikan Karakter sebagai Pendidikan Otak. In Mengatasi Masalah Narkoba dengan Welas Asih. Jakarta: Gramedia Pustaka Utama.

Pasiak, T. (2008). Revolusi IQ/EQ/SQ: Menyingkap Rahasia Kecerdasan Berdasarkan AlQuran dan Neurosains Mutakhir. Bandung: Mizan Bandung.

Rumadi. (2017). Taat Beribadah Tetapi Banyak Korupsi.

Sa'adi. (2011). A survey on the development of Islamic higher education in Indonesia: an epistemological review. IJIMS, Indonesian Journal of Islam and Muslim Societies, 1(1), 151-169.

Setiawan, B. (2016). Tradisi Ziarah Kubur: Agama Sebagai Konstruksi Sosial Pada Masyarakat di Bawean, Kabupaten Gresik. Biokultur, 5(2), 247-261. 
Suyadi, dkk: Constitutional Piety: The Integration of Anti-Corruption Education...

Sugiyono. (2015). Metode Penelitian Pendidikan: Pendekatan Kuantitatif, Kualitatif dan $R \& D$. Jakarta: Alfabeta. Retrieved from https://www.belbuk.com/metode-penelitianpendidikan-pendekatan-kuantitatif-kualitatif-dan-rd-p-10743.html

Sumaryati, Suyadi, D. H. (2019). Pendidikan Antikorupsi dalam Keluarga, Sekolah dan Masyarakat. Yogyakarta: UAD Press.

Suyadi. (2015a). Dasar-Dasar Pemikiran Menuju Ilmu Neurosains Pendidikan Islam. Yogyakarta: Sunan Kalijaga State Islamic University.

Suyadi. (2015b). Seri Pendidikan Antikorupsi Untuk SD/MI Kelas 1-6 Pendekatan TematikIntegratif. Yogyakarta: Andi Ofset.

Suyadi. (2016). Teori Pembelajaran Anak usia Dini Dalam Kajian Neurosains. Bandung: Rosda Karya.

Suyadi. (2018a). Integration Of Anti-Corruption Education Wth Neuroscience Approach (Multi-Ccase Study In Brain Friendly PUD: I Sleman Kindergarten Yogyakarta). Inferensi, Jurnal Penelitian Sosial Keagamaan, 12(2).

Suyadi. (2018b). The Synergy of Arts, Neuroscience, and Islamic In Early Childhood Learning In Yogyakarta. Tarbiya: Journal of Education in Muslim Society, 5(1), 30-42.

Umam, M. H. (2013). Pandangan Islam tentang Korupsi. Teosofi: Jurnal Tasawuf Dan Pemikiran Islam, 3, 462-482. 